\title{
Gene diversity, agroecological structure and introgression patterns among village chicken populations across North, West and Central Africa
}

Grégoire Leroy ${ }^{1,2}$, Boniface B Kayang ${ }^{3}$, Issaka AK Youssao ${ }^{4}$, Chia V Yapi-Gnaoré ${ }^{5}$, Richard Osei-Amponsah ${ }^{3}$, N'Goran E Loukou $^{5,6}$, Jean-Claude Fotsa ${ }^{7}$, Khalid Benabdeljelil ${ }^{8}$, Bertrand Bed'hom², Michèle Tixier-Boichard ${ }^{2}$ and Xavier Rognon ${ }^{1,2^{*}}$

\begin{abstract}
Background: Chickens represent an important animal genetic resource for improving farmers' income in Africa. The present study provides a comparative analysis of the genetic diversity of village chickens across a subset of African countries. Four hundred seventy-two chickens were sampled in 23 administrative provinces across Cameroon, Benin, Ghana, Côte d'Ivoire, and Morocco. Geographical coordinates were recorded to analyze the relationships between geographic distribution and genetic diversity. Molecular characterization was performed with a set of 22 microsatellite markers. Five commercial lines, broilers and layers, were also genotyped to investigate potential gene flow. A genetic diversity analysis was conducted both within and between populations.

Results: High heterozygosity levels, ranging from 0.51 to 0.67 , were reported for all local populations, corresponding to the values usually found in scavenging populations worldwide. Allelic richness varied from 2.04 for a commercial line to 4.84 for one population from Côte d'Ivoire. Evidence of gene flow between commercial and local populations was observed in Morocco and in Cameroon, which could be related to long-term improvement programs with the distribution of crossbred chicks. The impact of such introgressions seemed rather limited, probably because of poor adaptation of exotic birds to village conditions, and because of the consumers' preference for local chickens. No such gene flow was observed in Benin, Ghana, and Côte d'Ivoire, where improvement programs are also less developed. The clustering approach revealed an interesting similarity between local populations found in regions sharing high levels of precipitation, from Cameroon to Côte d'Ivoire. Restricting the study to Benin, Ghana, and Côte d'Ivoire, did not result in a typical breed structure but a south-west to north-east gradient was observed. Three genetically differentiated areas $(P<0.01)$ were identified, matching with Major Farming Systems (namely Tree Crop, Cereal-Root Crop, and Root Crop) described by the FAO.
\end{abstract}

Conclusions: Local chickens form a highly variable gene pool constituting a valuable resource for human populations. Climatic conditions, farming systems, and cultural practices may influence the genetic diversity of village chickens in Africa. A higher density of markers would be needed to identify more precisely the relative importance of these factors.

\footnotetext{
* Correspondence: xavier.rognon@agroparistech.fr

'AgroParisTech, UMR1313 Génétique Animale et Biologie Intégrative, Paris 05 F-75231 France

${ }^{2}$ INRA, UMR1313 Génétique Animale et Biologie Intégrative, Jouy-en-Josas 78352 France

Full list of author information is available at the end of the article
} 


\section{Background}

Knowledge-based management of animal genetic resources (AnGR) is critical to answer the current agricultural, socioeconomic, and environmental challenges. Consequently, characterization of AnGR constitutes one of the priorities of the FAO global plan of action for AnGR [1], in particular in developing countries, where there is a lack of information regarding what and how to conserve, develop, and select among local breeds.

Village poultry make a significant contribution to poverty alleviation and household food security in many developing countries [2]. About 1.5 billion chickens are raised in Africa, $80 \%$ of them belonging to local chicken populations [3]. Indigenous chickens are considered to make a significant contribution to food security and the economical sustainability of rural households [4-6]. However, little is known about their genetic diversity. A recent FAO survey has shown that economic drivers and poor livestock sector policies are the main threats to AnGR: intensification of agriculture, importation of exotic breeds, and indiscriminate cross-breeding [7]. In the case of poultry, poor conservation strategies represent a relatively important threat, and incentives for a continued and sustainable use of local populations are lacking. Conservation strategies require a good knowledge of the genetic structure of these local populations, within or between countries, as well as an assessment of their diversity at the molecular level, to provide recommendations regarding their future management. Several studies of the genetic diversity and structure of local chicken populations in Africa have been done separately for different countries [8-15], and very few have considered a larger region such as East Africa [16]. More specifically, possible relationships between genetic diversity and environmental conditions have been investigated for chicken populations with contrasted results depending on the country of study $[9,11,16]$. Thus, an integrated study encompassing several African countries is still lacking but is undoubtedly required in order to give a more complete analysis of the current diversity of local chickens on this continent, where domestic chickens arrived from various origins such as India and the Mediterranean area $[17,18]$.

The aim of the present study was to provide a largescale analysis of the genetic diversity of local chickens in several countries from the central, western and northern parts of the African continent, in order to address questions important for further conservation strategies. These questions deal with (i) the amount of genetic diversity found within these populations, (ii) the search for a possible correlation between the genetic structure and agroecological distribution, and (iii) the detection of a possible gene flow between local populations and commercial lines.

\section{Methods}

\section{Sample collection and genotypes}

The sampling design involved 5 countries (Benin, Côte d'Ivoire, Ghana, Cameroon, and Morocco). Blood samples were drawn from the wing vein of 472 local adult chickens. Samples representative of Benin, Côte d'Ivoire, and Ghana chicken populations were collected throughout each country (Table 1, Figure 1). These populations have been independently investigated in previous studies [12-14] respectively). For a given village investigated, a mean number of 2 households was randomly chosen, and, for a given household, 2 chickens were sampled on average ( $80 \%$ of females). The number of villages investigated for a given administrative region ranged from 2 to 21. Each sample was assigned geographical coordinates based upon the village positions. For Benin, samples from the northern area were obtained from the Borgou $(\mathrm{N}=38)$ and Donga $(\mathrm{N}=17)$ administrative regions, within a sampling zone lying between $9^{\circ} 13^{\prime}-10^{\circ} 10^{\prime} \mathrm{N}$ and $1^{\circ} 18^{\prime}-3^{\circ} 13^{\prime}$ E. Samples from the southern area came from the Atlantic $(\mathrm{N}=20)$, Couffo $(\mathrm{N}=10)$, Littoral $(\mathrm{N}=10)$, Mono $(\mathrm{N}=10)$, and Ouémé $(\mathrm{N}=8)$ regions, which lie between $6^{\circ} 12^{\prime}-6^{\circ} 37^{\prime} \mathrm{N}$ and $1^{\circ}$ $24^{\prime}-2^{\circ} 23^{\prime}$ E. For Côte d'Ivoire, only the southern area was covered, including the Lacs $(\mathrm{N}=41), \quad \mathrm{N} Z \mathrm{Zi}$-Comoé $(\mathrm{N}=22)$, Agnéby $(\mathrm{N}=18)$, Sud-Comoé $(\mathrm{N}=17)$, and Lagunes $(\mathrm{N}=19)$ regions, between $5^{\circ} 20^{\prime}-7^{\circ} 37^{\prime} \mathrm{N}$ and $2^{\circ}$ $56^{\prime}-5^{\circ} 27^{\prime} \mathrm{W}$. For Ghana, the northern area included the Northern $(\mathrm{N}=25)$, Upper-West $(\mathrm{N}=23)$, and Upper-East $(\mathrm{N}=5)$ regions, between $8^{\circ} 50^{\prime}-11^{\circ} 01^{\prime} \mathrm{N}$ and $0^{\circ} 03^{\prime}-2^{\circ} 51^{\prime}$ $\mathrm{W}$, while the southern area included the Western $(\mathrm{N}=32)$, Eastern $(\mathrm{N}=21)$, and Ashanti $(\mathrm{N}=6)$ regions, between $5^{\circ}$ $08^{\prime}-7^{\circ} 22^{\prime} \mathrm{N}$ and $0^{\circ} 39^{\prime}-2^{\circ} 49^{\prime} \mathrm{W}$. Cameroonian samples (sex-ratio 80\% of females) were obtained from local experimental stocks, reared at the Mankon Research Station, after incubating fertile eggs sampled from 93 villages distributed across four regions ([19]), namely the Centre (30 chicks), South (28 chicks), North-West/West (22 chicks), and East ( 5 chicks) regions lying between $2^{\circ} 50^{\prime}-7^{\circ}$ $\mathrm{N}$ and $10^{\circ}-15^{\circ}$ E. Moroccan samples $(\mathrm{N}=45)$ were randomly collected in the Agoudim village (Meknes region, in the Middle Atlas; $30^{\circ} 50^{\prime} \mathrm{N}-5^{\circ} 35^{\prime} \mathrm{W}$ ), on three remote sites spread over several kilometers. Within each site, 5 to 15 households were selected, 1 to 2 individuals were sampled for a given household (sex-ratio: 50/50). For comparative purposes and searching of potential gene flow, 5 commercial lines [20], including 3 broiler $(\mathrm{N}=25-29)$ and 2 layer $(\mathrm{N}=25)$ lines (Table 1$)$, were also analyzed. These lines were chosen to be representative of the main commercial lines usually imported into these countries, such as: white egg layers (Hy-line, Lohmann), brown egg layers (Isa Brown) and broilers (Cobb, Hubbard, Ross).

Genomic DNA was extracted from blood using the Qiagen ${ }^{\circledR}$ Kit (Qiagen, Valencia, CA, USA) at the 
Table 1 Origin and sample size of the 28 chicken populations

\begin{tabular}{|c|c|c|c|c|c|}
\hline Type & Country & Region & Code & Sample size & Location number \\
\hline Local & Benin & Atlantique & BEN-Atl & 20 & 1 \\
\hline \multirow[t]{23}{*}{ populations } & & Littoral & BEN-Lit & 10 & 2 \\
\hline & & Couffo & BEN-Cou & 10 & 3 \\
\hline & & Mono & BEN-Mon & 10 & 4 \\
\hline & & Ouémé & BEN-Oué & 8 & 5 \\
\hline & & Borgou & BEN-Bor & 38 & 6 \\
\hline & & Donga & BEN-Don & 17 & 7 \\
\hline & Côte & Agnéby & CIV-Agn & 18 & 8 \\
\hline & d'Ivoire & Sud-Comoé & CIV-SCo & 17 & 9 \\
\hline & & Lagunes & CIV-Lag & 19 & 10 \\
\hline & & Lacs & CIV-Lac & 41 & 11 \\
\hline & & N'Zi-Comoé & CIV-NCO & 22 & 12 \\
\hline & Ghana & Ashanti & GHA-Ash & 6 & 13 \\
\hline & & Eastern & GHA-Eas & 27 & 14 \\
\hline & & Western & GHA-Wes & 26 & 15 \\
\hline & & Northern & GHA-Nor & 25 & 16 \\
\hline & & Upper-East & GHA-UEa & 16 & 17 \\
\hline & & Upper-West & GHA-UWe & 12 & 18 \\
\hline & Maroc & Meknes & MAR-Mek & 45 & 19 \\
\hline & Cameroun & Centre & CAM-Cen & 30 & 20 \\
\hline & & Est & CAM-Est & 5 & 21 \\
\hline & & Sud & CAM-Sud & 28 & 22 \\
\hline & & Ouest/Nord-Ouest & CAM-ONO & 22 & 23 \\
\hline & & & & & \\
\hline \multirow[t]{3}{*}{ Broiler } & & Broiler-sire line- $C$ & $B S-C$ & 25 & \\
\hline & & Broiler-sire line-D & BS-D & 29 & \\
\hline & & Broiler-dam line-B & $\mathrm{BD}-\mathrm{B}$ & 25 & \\
\hline \multirow[t]{2}{*}{ Layer } & & White egg layer-A & WEL-A & 25 & \\
\hline & & Brown egg layer-C & BEL-C & 25 & \\
\hline
\end{tabular}

biotechnology laboratory of the University of Ghana (samples from Benin, Côte d'Ivoire, Ghana, and Cameroon) or using the $\mathrm{NaOH}$ extraction protocol at the IAV (Moroccan samples). A total of 601 individuals, including 472 local African chickens and 129 individuals from commercial lines, were genotyped for 22 microsatellite loci from the AvianDiv panel [21]. PCR amplification and genotyping were performed by the same laboratory (Labogena, France), using a capillary sequencer (ABI PRISM 3100 Genetic Analyzer; Applied Biosystems). Genotypes are available upon request.

\section{Statistical analysis}

Administrative provinces were considered as sampling units for performing preliminary estimations of genetic polymorphism. The presence of null alleles was tested using FreeNA [22]: loci with estimated frequencies of null alleles $r \geq 0.2$ could be considered to be potentially problematic for calculations. The allele frequencies, number of alleles, observed $\left(H_{o}\right)$, non-biased expected $\left(H_{e}\right)$ heterozygosity, and F-Statistics [23] were estimated using GENETIX 4.05.2 [24]. GENEPOP 4.07 [25] was used to evaluate departure from Hardy-Weinberg equilibrium and pairwise genic differentiation among breeds [26]. Allelic richness $(A r)$ was computed with the rarefaction method using FSTAT 2.9.3.2 [27]. Test significance was corrected with sequential Bonferroni correction on loci.

The matrix of Reynolds distances $\left(D_{R} ;\right.$ [28]) was computed using PHYLIP 3.69 [29]. Regarding the $D_{R}$ distance, a NeighborNet [30] network was drawn using SPLITSTREE 4.8 [31]. 


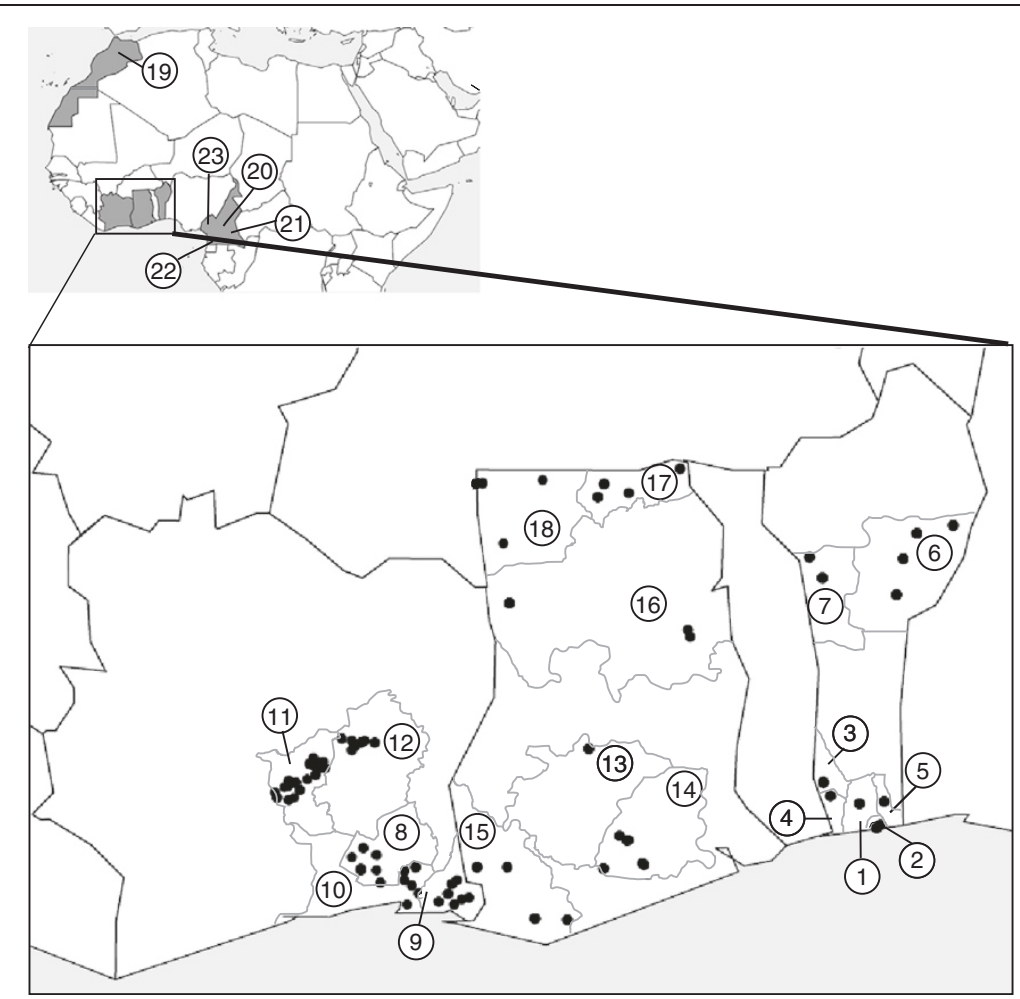

Figure 1 Geographic location of the 23 local chicken populations sampled throughout Côte d'Ivoire, Ghana, Benin, Cameroon and Morocco. Population units are numbered as indicated in Table 1. Dots represent collection sites for Benin, Ghana and Côte d'Ivoire.

Clustering approaches were performed, in a first step, on the 27 populations using a Bayesian clustering procedure implemented in STRUCTURE [32], considering a number of $\mathrm{K}$ clusters ranging from 1 to 16 . For each $\mathrm{K}, 100$ runs were performed with 100000 iterations following a burn-in period of 100 000, under admixture and correlated allele frequency model. As consistency across runs seems to be an informative method for assessing species structure across breeds [33,34], we used CLUMPP [35] to estimate the similarity function G' over runs for the different values of $\mathrm{K}$, using LARGEKGREEDY algorithm. We selected a subset of runs that included the run with the highest number of similar runs (symmetric similarity coefficients SSC higher than 0.95) and the corresponding runs. We used this subset to compute a mean Q-matrix. In a second step, analysis was reduced to the 326 individuals with exact coordinates from Benin, Côte d'Ivoire, and Ghana. A clustering approach was also conducted under the same conditions for $K=1$ to 6 . On the basis of membership coefficients for $K=2$, the genetic structure of the set was interpolated spatially with the Kriging approach, using the $\mathrm{R}$ procedure described by François [36]. Membership values, according to agroecological zones, were tested using $t$-test procedures.
Potential genetic introgression from commercial lines to local populations was investigated by computing the individual allele shared distance $(D A S)$ [37] matrix for each country, including all individuals from commercial lines. Matrices and dendrograms were obtained using POPULATION 1.2.28 [38] and TREEPLOT 0.7 [39] respectively.

\section{Results}

\section{Genetic variations}

Amongst the 22 markers, 188 alleles were identified, with the number of alleles per marker ranging from 2 to 23 (Additional file 1). When grouped by country or commercial lines altogether, total number of alleles ranged from 117 (commercial lines) to 156 (Côte d'Ivoire), number of private alleles ranged from 2 (Cameroon and Morocco) to 7 (Côte d'Ivoire), while allelic richness ranged from 4.85 (commercial lines) to 5.96 (Côte d'Ivoire).

$\mathrm{He}$ values ranged from 0.297 (WEL-A) to 0.665 (MARMek) with a mean value of $0.560( \pm 0.078)$, according to the genetic diversity indices of the studied populations (Table 2). $A r$ (computed for populations with more than 10 individuals genotyped for each locus) values rose from 2.04 (WEL-A) to 4.84 (CIV-SCo) with a mean value of $3.93( \pm 0.73)$. Fis ranged from -0.081 (BEN-Oué) to 0.131 
Table 2 Summary of genetic diversity measures across African and commercial populations

\begin{tabular}{|c|c|c|c|c|c|c|c|}
\hline sample & $\mathrm{He}$ & Ho & $M N A$ & $\operatorname{Ar}(N>10)$ & Fis & LEHWE & LDHWE \\
\hline BEN-Atl & 0.534 & 0.512 & 4.64 & 4.06 & 0.041 & & \\
\hline BEN-Lit & 0.588 & 0.613 & 4.41 & - & -0.044 & & \\
\hline BEN-Cou & 0.574 & 0.606 & 3.82 & - & -0.060 & & \\
\hline BEN-Mon & 0.562 & 0.558 & 3.95 & - & 0.008 & & \\
\hline BEN-Oué & 0.550 & 0.591 & 3.55 & - & -0.081 & & \\
\hline BEN-Bor & 0.548 & 0.540 & 5.14 & 3.95 & 0.013 & & \\
\hline BEN-Don & 0.526 & 0.503 & 4.14 & 3.81 & 0.046 & & \\
\hline CIV-Agn & 0.605 & 0.595 & 4.82 & 4.40 & 0.018 & & \\
\hline CIV-SCO & 0.638 & 0.616 & 5.32 & 4.84 & 0.036 & & 1 \\
\hline CIV-Lag & 0.612 & 0.574 & 4.77 & 4.40 & 0.064 & & \\
\hline CIV-LaC & 0.591 & 0.586 & 6.00 & 4.54 & 0.009 & & \\
\hline CIV-NCO & 0.553 & 0.528 & 5.05 & 4.30 & 0.045 & & 1 \\
\hline GHA-Ash & 0.565 & 0.561 & 3.64 & - & 0.009 & & \\
\hline GHA-Eas & 0.619 & 0.625 & 5.09 & 4.33 & -0.010 & & \\
\hline GHA-Wes & 0.612 & 0.583 & 5.14 & 4.32 & 0.048 & & 1 \\
\hline GHA-Nor & 0.571 & 0.551 & 4.95 & 4.25 & 0.035 & & \\
\hline GHA-UEa & 0.510 & 0.503 & 3.77 & 3.58 & 0.014 & & \\
\hline GHA-UWe & 0.561 & 0.553 & 4.18 & 4.18 & 0.015 & 1 & \\
\hline MAR-Mek & 0.665 & 0.579 & 5.36 & 4.48 & $0.131^{*}$ & & 2 \\
\hline CAM-Cen & 0.635 & 0.637 & 5.46 & 4.57 & -0.003 & & \\
\hline CAM-Est & 0.634 & 0.664 & 3.36 & - & -0.052 & & \\
\hline CAM-Sud & 0.632 & 0.647 & 5.55 & 4.54 & -0.024 & & \\
\hline CAM-ONO & 0.632 & 0.613 & 4.73 & 4.21 & 0.032 & & 1 \\
\hline BS-C & 0.499 & 0.512 & 3.09 & 2.92 & -0.025 & & \\
\hline BS-D & 0.481 & 0.475 & 3.55 & 3.13 & 0.012 & & \\
\hline$B D-B$ & 0.482 & 0.484 & 3.14 & 2.92 & -0.003 & & \\
\hline WEL-A & 0.297 & 0.295 & 2.14 & 2.04 & 0.008 & & \\
\hline BEL-C & 0.406 & 0.360 & 2.95 & 2.77 & $0.115^{*}$ & & 2 \\
\hline
\end{tabular}

He: non-biased expected heterozygosity; Ho: observed heterozygosity; MNA: mean number of alleles per locus; $\operatorname{Ar}(\mathrm{N}>10)$ : allelic richness computed for populations with more than 10 individuals genotyped for each locus; Fis*: significant value after sequential bonferroni correction; LDHWE/LEHWE: number of Loci in heterozygote Deficiency/Excess, after sequential Bonferroni correction.

(MAR-Mek). After sequential Bonferroni correction, 6 populations showed a significant deficit of heterozygotes for 1 or 2 loci, and one population exhibited 1 locus with heterozygote excess. Only two locus $\mathrm{x}$ population combinations out of 616 were identified with a potentially null allele $(r>0.2$; data not shown): MCW037 $\mathrm{x}$ CAM-Est and MCW330 x BEL-C. However, excluding these two loci had very minor effects on Fis and $\mathrm{He}$ (Wilcoxon test; $P$-value $>0.05$ ), suggesting that null alleles are not the main cause of significant Fis values. Hence we chose to conserve all 22 loci. Testing population differentiation, 112 pairs of populations were found as non-significantly differentiated out of the 378 tests performed (Additional file 2). All pairwise comparisons involving either commercial lines or the Moroccan population were significant. Within the 6 pairwise comparisons among Cameroon chicken populations, only 2 were significant. The CAM-Est sample could not be differentiated from several populations of Côte d'Ivoire (CIV-SCo and CIV-Lag) or Ghana (GHA-Ash, GHA-Eas and GHA-Wes). Furthermore, CIV-SCo was not differentiated from CAM-Cen and CAM-Sud and CIV-Lag was not differentiated from CAM-Cen. All the other non significant pairwise tests (100) involved pairwise comparisons within or among Benin, Côte d'Ivoire, and Ghana.

\section{Population relationships and clustering}

The use of the Bayesian clustering approach allows estimating the genetic structure within the population studied, using either the Q-matrix averaged over the most similar runs for $\mathrm{K}=2$ to 9 (Figure 2, see material and methods) or overall runs for $\mathrm{K}=2$ to 16 (Additional file 3). As $\mathrm{K}$ increased, the likelihood $(\operatorname{Ln}(\mathrm{P}(\mathrm{D})))$ increased until $\mathrm{K}=9$ and stabilized afterwards, while its standard deviation increased (Additional file 4), indicating that $\mathrm{K}=9$ captures the major structure proportion present in the data, and that only a minor proportion of the genetic structure is described by higher $\mathrm{K}$ values $[40,41]$. From $\mathrm{K}=2$, most African chicken populations appeared clearly differentiated from commercial lines and the Moroccan population, with Cameroon chicken populations showing intermediate results (Figure 2). As $\mathrm{K}$ increased, the two layer lines appeared to be quickly differentiated (for $\mathrm{K}=3$ and 5), while some differentiation appeared within the African populations. All individuals from Benin and the Ghanaian chickens from GHA-UEa and GHA-UWe regions formed one cluster, which differed from the cluster formed by the remaining Ghanaian individuals, Côte d'Ivoire, Cameroonian, and most of Moroccan samples. However, these results could not be generalized for African chicken populations at the individual level, and there was a relatively high heterogeneity of membership coefficients within populations, particularly in comparison with commercial lines. The genetic structure appeared more complex as $\mathrm{K}$ increased. Regarding Morocco for instance, the population could be divided into two groups according to their admixture coefficient: the first one, more numerous, was found close to African populations but was completely differentiated from $K=8$, while the second one included individuals belonging to the same cluster as broiler lines (14 individuals with membership coefficients greater than 0.5 for $K=6$ ). These individuals were differentiated from broiler samples only from $K=14$ (Additional file 3). It was also observed that a few individuals from Morocco shared a relatively high membership coefficient for the cluster specific to the brown-egg commercial line (BEL-C): for $K=6,3$ individuals had 


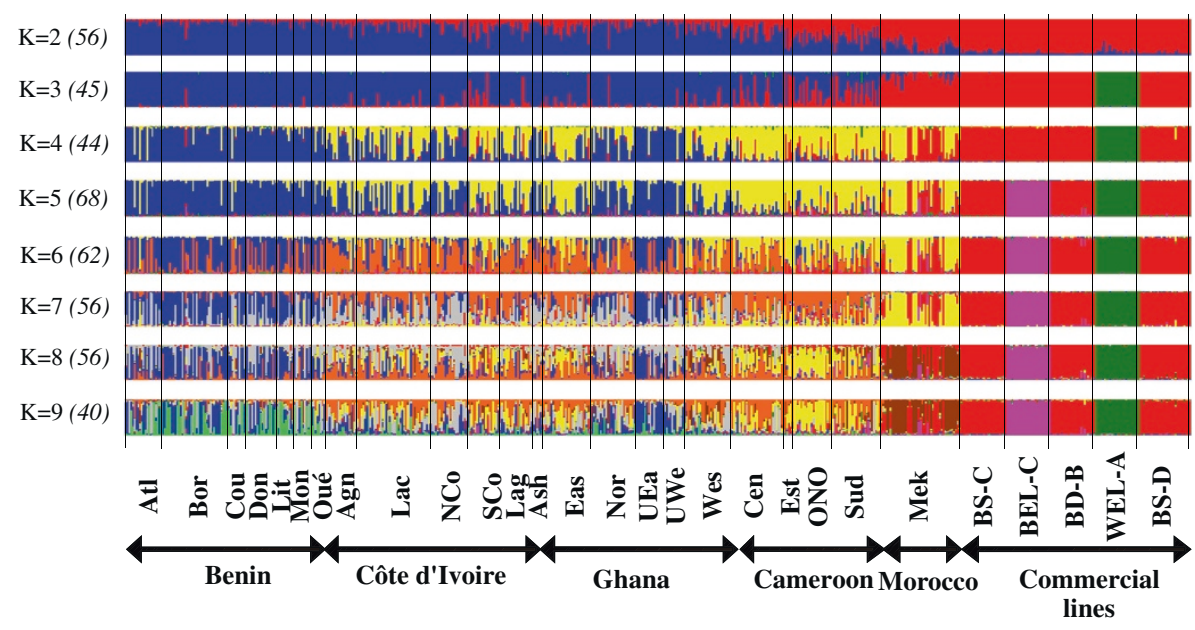

Figure 2 Estimated membership coefficients of each individual to the inferred $\mathrm{K}$ cluster, with $\mathrm{K}=\mathbf{2 - 9}$. In brackets, the number of runs with similar solutions (SSC > 0.95) that has been used to compute the mean Q-matrix.

membership coefficients between 0.42 and 0.46 . When using the Q-matrix averaged over the 100 runs (Additional file 3), we noticed that the five commercial lines could be clearly differentiated. The white-egg layer (WEL-A) was, in general, the first one to differentiate within this group, which was expected since it derives from the single breed White Leghorn. The other lines shared Asiatic origins; however, different breed histories led to their differentiation as $\mathrm{K}$ increased.

Structure analysis was then restricted to individuals sampled in the area including Ghana, Benin, and Côte d'Ivoire. Following the higher likelihood found for $\mathrm{K}=2$ (Additional file 5), the results interpolated using geographical coordinates are given in Figure 3, showing that individuals were distributed along a north-east/ south-west cline. The north-east side included all Beninese samples, GHA-UEa, GHA-UWe, and GHA-Nor (the results being intermediate for one of the GHA-Nor sampling sites). The largest membership values were found within BEN-Don and GHA-UEa (cluster 1 membership $>0.62$ ) regions. All the samples from Côte d'Ivoire, GHA-Ash, GHA-Eas, and GHA-Wes were found at the south-west side. The lowest values were found within CIV-SCo and GHA-Eas (cluster 1 membership $<0.40$ ).

According to the $D_{R}$ distances (Additional file 2), the Neighbor-Net network restricted on African populations (Figure 4) confirmed the results found through geographical interpolation with regards to the genetic relationships among populations from Côte d'Ivoire, Ghana, and Benin. According to the network, chicken samples from Cameroon and Morocco were found to be genetically closer to the south-west group; this was in agreement with STRUCTURE general results (Figure 2). Adding commercial lines did not change the results
(Additional file 6). Those lines were found to be largely differentiated in comparison to the other populations.

Individual dendrograms (Additional files 7, 8, 9, 10 and 11) established for the different countries showed that some local chickens were intermingled with chickens from commercial lines. If no individuals from Benin were classified with commercial chickens, this was the case for a few individuals from Côte d'Ivoire and Ghana (1 and 3 respectively), all of them being found at the periphery of

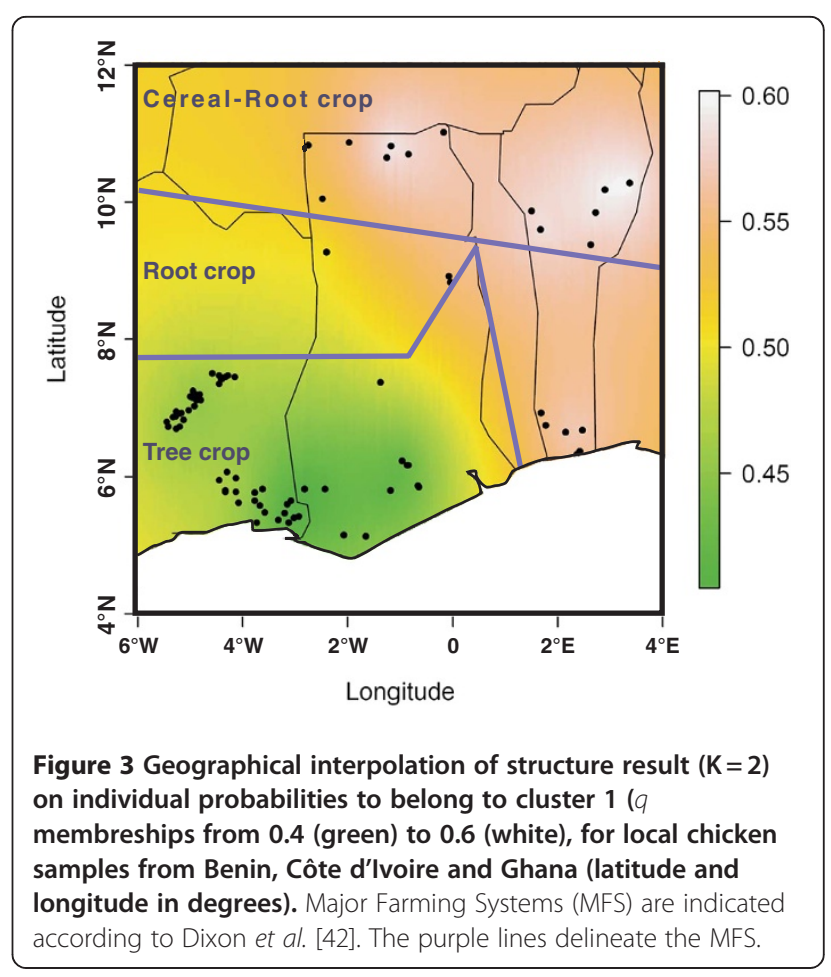




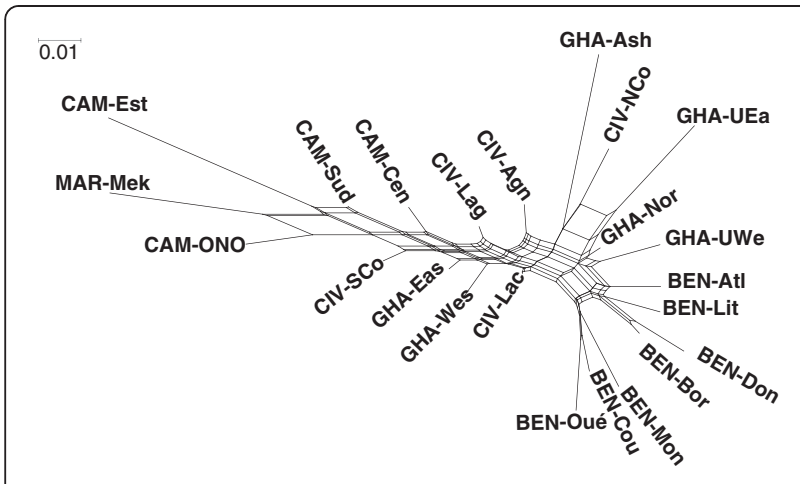

Figure 4 Neighbour-Net for the 23 African local chicken populations, based on Reynolds $D_{R}$ distance.

commercial clusters. A much larger number of individuals from Cameroon were misclassified, while chickens from Morocco were separated into different clusters distributed across commercial lines. When compared with individual membership results from the STRUCTURE approach (for $\mathrm{K}=6$ ), chickens with $q i>0.2$ for clusters specific to commercial lines were in general clustered in small groups (Additional files 10 and 11), even if they were not always assigned close to commercial clusters. Note also that the BEL cluster, if always clearly defined, plotted with the other selected in three cases (Benin, Ghana, and Morocco, Additional files 7, 9 and 11 respectively) but was positioned within the local population for the two other cases (Côte d'Ivoire and Cameroon, Additional files 8 and 10 respectively).

\section{Discussion}

\section{Gene diversity and gene flow}

Several studies have been published which include a large collection of chicken populations genotyped with microsatellite markers $[8,10,20,21,43,44]$. Heterozygosity levels reported here, for the 23 local African chicken populations, were similar to the values found in other scavenging populations, in Africa or in Asia, ranging from 0.53 to 0.7 $[8,9,11,15,16,44-46]$ and being larger than those found in standardized (fancy) breeds (0.28-0.63) or commercial lines $(0.34-0.63)$ [10,21,47]. Such levels can be expected for domestic populations which are not selected and have not been submitted to any bottlenecks in a recent past.

Since introgression from commercial lines may constitute a major issue for conservation and management of local chicken populations $[6,11]$, we tried to assess the evidence and impact of such gene flows. Two contrasted situations were observed. In the first case, involving populations from Benin, Ghana, and Côte d'Ivoire, introgression can be considered as negligible or limited, although introduction of commercial lines in these countries has taken place (see $[48,49]$ for some examples in Côte d'Ivoire). In the second case, observed in Cameroon and Morocco, clustering results and individuals' dendrograms suggest that such gene flows have impacted the population structure to some extent. Observations on phenotypic variability may be used to confirm this suggestion because some traits are quite typical of commercial lines. This is the case of the yellow shank phenotype due to a recessive autosomal mutation at the $W$ locus [50] found in all commercial layers, either white-egg or brown-egg, and in several broiler lines, whereas the wild type is a grey-blue shank colour. Previous surveys showed that the yellow shank phenotype is quite rare in Benin (5\% [14]) and Côte d'Ivoire (15\% [51]) or in other African countries such as Senegal (4\% [52]), while it is much more common either in Cameroon (31 to 38\% [53,54]) or Morocco $(60 \%$ in the studied sample; Benabdeljelil, personal observation). Furthermore, the presence of the $W$ mutation was found to be correlated with an improvement of anatomical traits in Cameroon [55]. In Cameroon also, the dwarf phenotype (allele $D W$ ) found in low frequency in some regions, may also indicate commercial introgression from broiler lines [54].

As in other places in Africa, several cooperating programs (FAO, bilateral cooperation, NGO...) were set up in these countries in order to improve poultry production, some of these involving the introduction of exotic cockerels for genetic improvement. Differences in the temporal framework of these programs could be, at least partially, responsible for the contrasting patterns of genetic introgression observed in our study. On the one hand, long-term operations took place in Morocco and Cameroon. In Morocco [56], the first poultry station was built in 1920 at Meknes. More recently, commercial hatcheries could supply traditional farmers with either male chicks of commercial layer lines or crossbred chicks obtained from Rhode Island and slow-growing meat type lines, such as French label and Barred Plymouth Rock. In Cameroon [57], supply of chicks to farmers was conducted by three pilot stations from 1960 to 1984 . In these cases, introduction of exotic chickens within the local livestock was more or less continuous for a long time. On the other hand, Ghana [58], Benin [59], or Côte d'Ivoire [49] operations were characterized by short-term actions: some programs for poultry development, with the introduction of limited numbers of cockerels, have been registered and, according to our results, had a very limited genetic impact on the local chicken gene pool.

Yet, taking into account the duration of exotic cocks introduction, genetic introgression appears finally relatively low even in Morocco and Cameroon. Limited impact of introductions may be explained by a poor adaptation of the genotypes introduced to local conditions or by the consumer's preference. Indeed, 
commercial lines have been counter-selected against broodiness, and then females have lost the ability to incubate their eggs naturally, whereas this ability is particularly important for self propagation of village chickens in harsh environments. Although the genetic determinism of broodiness is still under study [60], it is expected that $F_{1}$ females from exotic cocks are not as successful as the local hens in natural reproduction and chick rearing. Furthermore, commercial chicks have been selected with an optimum feeding system, and may not satisfy their nutritional needs in scavenging conditions. According to some authors [3,61], there is a consumer preference for local chickens, both for meat and eggs. Such preference has the effect that the sale price of local chickens (and eggs) is higher than that of products from commercial lines in African countries, including those studied here $[49,56-59,62,63]$. We also observed that phenotypic variability is very important due to the diversified social uses of local chickens $[51,54,64]$ such as religious rituals or indigenous pharmacopeia. Some traits may be retained from industrial birds when they have a relative advantage, particularly the white color, as described by [6] who observed that a white plumage color was a peace symbol in Benin. Plumage color is determined by major genes which may interact with each other. Some of these genes may have been introgressed from commercial lines into local chickens, as in the case of the yellow shank due to an autosomal recessive mutation [50].

\section{Chicken population structure}

Usually, scavenging chicken populations do not exhibit a typical breed structure $[11,15,45,65]$ even if some more or less marked differentiation could eventually be found $[9,46]$, in particular for large geographical data sets involving several African countries [16]. When considering our data globally, we found the same result. Yet, some relations with climatic conditions may be observed: local chickens from regions with high precipitations (>1400 mm/year [66]), i.e. south-eastern Côte d'Ivoire, southern Ghana, and Cameroon, seemed to share a similar genetic background according to Structure results (Figure 2) in contrast to chickens of the other regions with lower precipitations. The fact that a similar diversity pattern was found both in Cameroon and in southern Ghana/Côte d'Ivoire seems to indicate that such an observation could not result from genetic drift only. Restricting the analysis to Côte d'Ivoire, Ghana, and Benin, made it possible to identify a northeast/south-west cline illustrated in Figure 3. According to the FAO [42], this area may be divided into three Major Farming Systems (MFS). Considering our genetic differentiation results (Figure 3), the Tree Crop Farming System (TCFS) corresponds to the south-west side of the cline, involving Côte d'Ivoire and southern Ghana, while the
Cereal-Root Crop Farming System (C-RCFS) lies on the north-east side (northern part of Ghana and Benin). An intermediate area corresponding to the Root Crop Farming System (RCFS) and including middle Ghana and southern Benin exhibited a more similar pattern to CRCFS, both for genetic data and farming system. On the basis of Structure results, the three zones showed significantly different membership values $(P<0.01$ for RCFS/C-RCFS comparison and $P<0.001$ for the two other ones). Within the RCFS, according to surveys conducted in Benin [14], the weight and body measures of Savannah chickens (north of Benin) were found to be significantly higher than those of Forest chickens (south of Benin). Experimental comparisons [67] showed the same difference, suggesting that it could correspond, to some extent, to genetic effects, although no significant difference $(P=0.059)$ was observed between animals of northern and southern part of Benin, according to the Structure analysis restricted to Benin, Ghana, and Côte d'Ivoire (based on the individuals $q_{i}$ ). The number of markers used may be too limited to ensure detection of a genetic differentiation on a quantitative trait such as growth.

Human settlements and migrations may constitute another driving factor for the genetic structure of chicken populations. Although not well documented, there is a lot of movement of chickens between these countries as a result of long history of trade and migration. In particular, a large part of the human groups living in the south-east part of Côte d'Ivoire and south-west part of Ghana belong to the same ethnic group, namely the Akan, originating from Ghana $[68,69]$. Among others, these groups share most of the same cultural practices [70] implying similar uses of chicken resources [51] as part of this cultural background. Nevertheless, the admixture pattern could be related to commercial exchanges amplified by the high mobility of the people and the fact that chickens can be easily freighted [51], limiting the extent of genetic differentiation among areas.

These agroecological, cultural and demographic factors could result in genetic drift, gene flows or adaptation phenomena, and therefore explain the genetic structure pattern found across these countries. On the basis of the present data, it is, however, difficult to assess to what extent each of these factors has impacted genetic differentiation of these chicken populations.

\section{Conclusion}

African local chickens form a highly variable gene pool which constitutes a valuable resource for human populations. There is a large number of driving forces playing either for or against population differentiation of local chickens. Molecular studies bring complementary information to social surveys and phenotypic data, and allows to set up an integrated program of characterization and 
conservation of indigenous populations, as recommended by the FAO $[1,71]$. In this study, we were able to prove that such differentiation may exist among chicken populations, nevertheless, the relative importance of climatic influences and social practices are difficult to disentangle. Further analysis with a higher density of markers is necessary to ascertain the genetic structure of local chicken populations with a higher accuracy, and landscape genomics approaches would be useful to connect genetic differentiation with environmental conditions [72].

\section{Additional files}

Additional file 1: Summary of polymorphic measures for microsatellite markers. For each and over all populations or within each African country's population or commercial line, the following information are given: allele range, number of alleles $(A)$, number of private alleles $(A p)$ and allelic richness $(A r)$.

Additional file 2: Pairwise genetic distances $\left(D_{R}\right)$ and levels of significance of genic differentiation among the 28 chicken populations. $D_{R}$ values are above the diagonal and levels of significance are below the diagonal. For population codes, see Table 1.

Additional file 3: STRUCTURE analysis involving all 28 populations (23 African local chicken populations and 5 commercial lines), for $K=2-16$, using Q-matrix averaged overall 100 runs.

Additional file 4: STRUCTURE analysis involving all 28 populations (23 African local chicken populations and 5 commercial lines). Evolution of (a) likelihood $L n(P(D))$ and (b) similarity function $G^{\prime}$ according to the number of cluster $K$ $(\mathrm{K}=1$ to 16$)$.

Additional file 5: STRUCTURE analysis restricted to the 18 African local chicken populations from Ghana, Benin and Côte d'lvoire. Evolution of likelihood $L n(P(D))$ according to the number of cluster $K(K=1$ to 6$)$.

Additional file 6: Neighbor-Net for the complete dataset (23 African local chicken populations and 5 commercial lines), based on Reynolds $D_{R}$ distance.

Additional file 7: Individual neighbor-joining dendrogram based on DAS distance among 242 samples representing local chickens from Benin $(n=113)$ and 5 commercial lines $(n=129)$. red: Benin; orange: BS-D; dark green: BS-C; dark blue: Bel-C; light green: Wel-A; light blue: BD-B; black star indicates individuals with $q_{i}>0.2$, for clusters specific to commercial lines (STRUCTURE analysis for $\mathrm{K}=6$ ).

Additional file 8: Individual neighbor-joining dendrogram based on DAS distance among 250 samples representing local chickens from Côte d'Ivoire $(n=121)$ and 5 commercial lines $(n=129)$. red: Côte d'lvoire; orange: BS-D; dark green: BS-C; dark blue: Bel-C; light green: Wel-A; light blue: BD-B; black star indicates individuals with $q_{i}>0.2$, for clusters specific to commercial lines (STRUCTURE analysis for $\mathrm{K}=6$ ).

Additional file 9: Individual neighbor-joining dendrogram based on DAS distance among 241 samples representing local chickens from Ghana $(n=112)$ and 5 commercial lines $(n=129)$. red: Ghana; orange: BS-D; dark green: BS-C; dark blue: Bel-C; light green: Wel-A; light blue: BD-B; black star indicates individuals with $q_{i}>0.2$, for clusters specific to commercial lines (STRUCTURE analysis for $\mathrm{K}=6$ ).

Additional file 10: Individual neighbor-joining dendrogram based on DAS distance among 214 samples representing local chickens from Cameroon $(n=85)$ and 5 commercial lines $(n=129)$. red: Cameroon; orange: BS-D; dark green: BS-C; dark blue: Bel-C; light green: Wel-A; light blue: BD-B; black star indicates individuals with $q_{i}>0.2$, for clusters specific to commercial lines (STRUCTURE analysis for $\mathrm{K}=6$ ).

Additional file 11: Individual neighbor-joining dendrogram based on DAS distance among 175 samples representing local chickens from Morocco $(n=46)$ and 5 commercial lines $(n=129)$. red: Morocco; orange: BS-D; dark green: BS-C; dark blue: Bel-C; light green: Wel-A; light blue: BD-B; black star indicates individuals with $q_{i}>0.2$, for clusters specific to commercial lines (STRUCTURE analysis for $\mathrm{K}=6$ ).

\section{Competing interest}

The authors declare that they have no competing interests.

\section{Acknowledgments}

We would like to thank farmers from Ghana, Benin, Côte d'Ivoire, Cameroon and Morocco for their cooperation in obtaining samples. We also thank JeanLuc Coville, Nicolas Bruneau (INRA), Aurélie Thomas (LABOGENA) and Ahmed Nabich (IAV) for their laboratory assistance. We thank Mrs Tatiana Zerjal and Wendy Brand-Williams for linguistic revision. This study was financially supported by the Duras Project DCG1-08, IRAD-Cameroon, AgroParisTech and INRA.

\section{Author details}

1'AgroParisTech, UMR1313 Génétique Animale et Biologie Intégrative, Paris 05 F-75231 France. ${ }^{2}$ INRA, UMR1313 Génétique Animale et Biologie Intégrative, Jouy-en-Josas 78352 France. ${ }^{3}$ University of Ghana, Legon Ghana. ${ }^{4}$ Université d'Abomey-Calavi, Ecole Polytechnique d'Abomey-Calavi, Cotonou 01 BP 2009 Bénin. ${ }^{5}$ Centre National de la Recherche Agronomique, Abidjan 01 BP 1740 Côte d'Ivoire. 'Université de Cocody, Abidjan 22 BP 1244 Côte d'Ivoire.

${ }^{7}$ Station Spécialisée de Recherche Agricole de Mankon (SRRAD), Bamenda BP 4099 Cameroun. ${ }^{8}$ Institut Agronomique et Vétérinaire Hassan II, DPBA, Rabat Instituts, 10101, Rabat BP 6202 Maroc.

\section{Authors' contributions}

$X R$, IAKY, BBK, CVYG, KB and MTB conceived the project; IAKY, BBK, CVYG, ROA, NEL, JCF, KB, XR and BB collected the samples and data; XR and GL analysed the data; XR, GL and MTB led the writing, and all the authors participated in the discussion. All authors read and approved the final manuscript.

Received: 4 November 2011 Accepted: 7 May 2012 Published: 7 May 2012

\section{References}

1. FAO: The Global Plan of Action for Animal Genetic Resources and the Interlaken Declaration on Animal Genetic Resources. Rome, Italy: FAO; 2007.

2. Alders RG, Pym RAE: Village poultry: still important to millions, eight thousand years after domestication. World Poultry Sci J 2009, 65:181-190.

3. Gueye EF: Village egg and fowl meat production in Africa. World Poultry Sci J 1998, 54:73-86.

4. Gueye EF: Employment and income generation through family poultry in low-income food-deficit countries. World Poultry Sci J 2002, 58:541-557.

5. Aboe P, Boa-Amponsem K, Okantah S, Dorward P, Bryant M: Free-range village chickens on the Accra Plains, Ghana: Their contribution to households. Trop Anim Health Prod 2006, 38:223-234.

6. Faustin V, Adégbidi VF, Garnett ST, Koudandé DO, Agbo V, Zander KK: Peace, health or fortune? Preferences for chicken traits in rural Benin. Ecol Econ 2010, 69:1848-1857.

7. FAO: Threats to animal genetic resources -their relevance, importance and opportunities to decrease their impact, Commission on genetic resources for food and agriculture. Background study paper n50. 59. Rome Italy: FAO; 2009.

8. Wimmers K, Ponsuksili S, Hardge T, Valle-Zarate A, Mathur PK, Horst P: Genetic distinctness of African, Asian and South American local chickens. Anim Genet 2000, 31:159-165.

9. Msoffe PLM, Mtambo MMA, Minga UM, Juul-Madsen HR, Gwakisa PS: Genetic structure among the local chicken ecotypes of Tanzania based on microsatellite DNA typing. Afr J Biotechnol 2005, 4:768-771.

10. Granevitze Z, Hillel J, Chen GH, Cuc NTK, Feldman M, Eding H, Weigend S: Genetic diversity within chicken populations from different continents and management histories. Anim Genet 2007, 38:576-583.

11. Muchadeyi FC, Eding H, Wollny CBA, Groeneveld E, Makuza SM, Shamseldin $\mathrm{R}$, Simianer $\mathrm{H}$, Weigend $\mathrm{S}$ : Absence of population substructuring in Zimbabwe chicken ecotypes inferred using microsatellite analysis. Anim Genet 2007, 38:332-339.

12. Loukou NE, Yapi-Gnaoré CV, Gnénékita T, Coulibaly Y, Rognon X, Kayang BB, Youssao IAK, Tixier-Boichard M, N'guetta ASP: Evaluation de la diversité des poulets traditionnels de deux zones agroecologiques de Côte d'Ivoire à I'aide de marqueurs microsatellites.J Anim Plant Sci 2009, 5:425-436.

13. Osei-Amponsah R, Kayang BB, Naazie A, Osei YD, Youssao IAK, Yapi-Gnaoré VC, Tixier-Boichard M, Rognon X: Genetic diversity of Forest and Savannah 
chicken populations of Ghana as estimated by microsatellite markers. Anim Sci Journal 2010, 81:297-303.

14. Youssao IAK, Tobada PC, Koutinhouin BG, Dahouda M, Idrissou ND, Bonou GA, Tougan UP, Ahounou S, Yapi-Gnaoré V, Kayang B, Rognon X, TixierBoichard M: Phenotypic characterisation and molecular polymorphism of indigenous poultry populations of the species Gallus gallus of Savannah and Forest ecotypes of Benin. Afr J Biotechnol 2010, 9:369-381.

15. Mtileni BJ, Muchadeyi FC, Maiwashe A, Groeneveld E, Groeneveld LF, Dzama $\mathrm{K}$, Weigend S: Genetic diversity and conservation of South African indigenous chicken populations. J Anim Breed Genet 2011, early view: http://dx.doi.org/10.1111/j.1439-0388.2010.00891.x.

16. Mwacharo JM, Nomura K, Hanada H, Jianlin H, Hanotte O, Amano T: Genetic relationships among Kenyan and other East African indigenous chickens. Anim Genet 2007, 38:485-490

17. Williamson K: Did chickens go west? In The origins and development of African livestock. Edited by Blenck RM, MacDonald KC. London, New-York: UCL Press; 2000:368-448,

18. MacDonald KC: The domestic chicken (Gallus gallus) in sub-saharan Africa: a background to its introduction and its osteological differentiation from indigenous fowls (Numidinae and Francolinus sp.). J Archeaol Sci 1992, 19:303-318.

19. Fotsa JC, Poné Kamdem D, Rognon X, Tixier-Boichard M, Meffeja, Tchoumboué J, Manjeli Y, Bordas A: Etudes comparées des caractéristiques de ponte de la poule camerounaise (Gallus gallus) et d'un label. Bull Anim Hlth Prod Afr 2011, 59:239-251.

20. Hillel J, Groenen MAM, Tixier-Boichard M, Korol AB, David L, Kirzhner VM, Burke T, Barre-Dirie A, Crooijmans RPMA, Elo K, Feldman MW, Freidlin PJ, Mäki-Tanila A, Oortwijn M, Thomson P, Vignal A, Wimmers K, Weigend S: Biodiversity of 52 chicken populations assessed by microsatellite typing of DNA pools. Genet Sel Evol 2003, 35:533-557.

21. Berthouly C, Bed'Hom B, Tixier-Boichard M, Chen CF, Lee YP, Laloë D, Legros $H$, Verrier E, Rognon X: Using molecular markers and multivariate methods to study the genetic diversity of local European and Asian chicken breeds. Anim Genet 2008, 39:121-129.

22. Chapuis MP, Estoup A: Microsatellites null alleles and estimation of population differentiation. Mol Biol Evol 2007, 24:621-631.

23. Weir BS, Cockerham CC: Estimating F-statistics for the analysis of population structure. Evolution 1984, 38:1358-1370.

24. Belkhir K, Borsa P, Goudet J, Chikhi L, Bonhomme F: GENETIX, logiciel sous Windows TM pour la génétique des populations. In Laboratoire Génome, Populations, Interactions: CNRS.UPR. 9060. Edited by. Montpellier, France: Université Montpellier II; 2004. version 4.0.3.

25. Rousset F: Genepop'007: a complete re-implementation of the genepop software for Windows and Linux. Mol Ecol Res 2008, 8:103-106

26. Goudet J, Raymond M, de-Meeus T, Rousset F: Testing Differentiation in Diploid Populations. Genetics 1996, 144:1933-1940.

27. Goudet J: FSTAT, a program to estimate and test gene diversities and fixation indices. J Hered 1995, 86:485-486 [version 2.9.3: available from http://www2.unil.ch/popgen/softwares/fstat.htm]

28. Reynolds J, Weir BS, Cockerham CC: Estimation of the coancestry coefficient: basis for a short-term genetic distance. Genetics 1983, 105:767-779.

29. Felsenstein J: PHYLIP - Phylogeny Inference Package (Version 3.2). Cladistics 1989, 5:164-166.

30. Bryant D, Moulton V: Neighbor-Net: An Agglomerative Method for the Construction of Phylogenetic Networks. Mol Biol Evol 2004, 21:255-265.

31. Huson DH, Bryant D: Application of Phylogenetic Networks in Evolutionary Studies. Mol Biol Evol 2006, 23:254-267.

32. Pritchard JK, Stephens M, Donnelly P: Inference of Population Structure Using Multilocus Genotype Data. Genetics 2000, 155:945-959.

33. Wang S, Lewis CM Jr, Jakobsson M, Ramachandran S, Ray N, Bedoya G, Rojas W, Parra MV, Molina JA, Gallo C, et al: Genetic Variation and Population Structure in Native Americans. PLoS Genet 2007, 3(11):e185.

34. Leroy G, Verrier E, Meriaux JC, Rognon X: Genetic diversity of dog breeds: within-breed diversity comparing genealogical and molecular data. Anim Genet 2009, 40:323-332.

35. Jakobsson M, Rosenberg NA: CLUMPP: a cluster matching and permutation program for dealing with label switching and multimodality in analysis of population structure. Bioinformatics 2007, 23:1801-1806.

36. François O: How to display admixture coefficients (Q matrix) spatially? [http://membres-timc.imag.fr/Olivier.Francois/admix_display.html].
37. Jin $L$, Chakraborty R: Estimation of genetic distance and coefficient of gene diversity from single-probe multilocus DNA fingerprinting data. Mol Biol Evol 1994, 11:120-127.

38. Langella O: Populations version 1.2.28., [http://www.bioinformatics.org/ project/?group_id=84].

39. Langella O: Treeplot version 0.7., [https://sourcesup.cru.fr/projects/treeplot/].

40. Evanno G, Regnaut S, Goudet J: Detecting the number of clusters of individuals using the software structure: a simulation study. Molecular Ecology 2005, 14:2611-2620.

41. Pritchard JK, Wen X, Falush D: Documentation for structure software: Version 2.3. 2010, [http://pritch.bsd.uchicago.edu/structure.html].

42. Dixon J, Gulliver A, Gibbon D: Farming Systems and Poverty: Improving Farmers' Livelihoods in a Changing World. Rome: FAO; 2001.

43. Rosenberg NA, Burke T, Elo K, Feldman MW, Freidlin PJ, Groenen MAM, Hillel J, Maki-Tanila A, Tixier-Boichard M, Vignal A, et al: Empirical Evaluation of Genetic Clustering Methods Using Multilocus Genotypes From 20 Chicken Breeds. Genetics 2001, 159:699-713.

44. Qu L, Li X, Xu G, Chen K, Yang H, Zhang L, Wu G, Hou Z, Xu G, Yang N: Evaluation of genetic diversity Chinese indigenous chicken breeds using microsatellite markers. Sci China C Life Sci 2006, 49:332-341.

45. Berthouly C, Leroy G, Nhu Van email T, Hoang Thanh H, Bed'hom B, Trong Nguyen B, Vu Chi C, Monicat F, Tixier-Boichard M, Verrier E, Maillard JC, Rognon X: Genetic analysis of local Vietnamese chickens provides evidence of gene flow between domestic and wild populations. BMC Genet 2009, 10:1

46. Cuc NTK, Simianer H, Eding H, Tieu HV, Cuong VC, Wollny CBA, Groeneveld $L F$, Weigend S: Assessing genetic diversity of Vietnamese local chicken breeds using microsatellites. Anim Genet 2010, 41:545-547.

47. Tadano R, Sekino M, Nishibori M, Tsudzuki M: Microsatellite marker analysis for the genetic relationships among Japanese long-tailed chicken breeds. Poultry Sci 2007, 86:460-469.

48. Zana O, Aman N, Kouassi NF, Zoumana C: Enquête sur la production avicole traditionnelle en milieu rural an nord de la Côte d'Ivoire: cas de la zone dense de Korhogo. Agron Afr 1999, 11:49-56.

49. Kone S, Danho T: Etude du secteur avicole en Côte d'Ivoire, structure, importance et perspective. Cas de l'aviculture semi-industrielle. In Revue du Secteur Avicole. Edited by FAO.: Animal Production and Health Division; 2008 [available at http://www.fao-ectad-bamako.org/fr/IMG/pdf/ Cote_d_Ivoire_FR_.pdf].

50. Eriksson J, Larson G, Gunnarsson U, Bed'hom B, Tixier-Boichard M, Strömstedt L, Wright D, Jungerius A, Vereijken A, Randi E, et al: Identification of the Yellow Skin Gene Reveals a Hybrid Origin of the Domestic Chicken. PLoS Genet 2008, 4(2):e1000010. doi:10.1001371/journal. pgen.1000010

51. Yapi-Gnaoré V, Loukou NGE, N'guetta ASP, Kayang B, Rognon X, TixierBoichard M, Touré G, Coulibaly Y, Youssao IAK: Diversités phénotypique et morphométrique des poulets locaux (Gallus gallus) de deux zones agroécologiques de Côte d'Ivoire.Cah Agric 2010, 19:439-445.

52. Missohou A, Sow RS, Ngwe-Assoumou C: Caractéristique morphologique des poulets du Sénégal. Anim Genet Res 1998, 24:63-69.

53. Keambou TC, Boukila B, Moussounda G, Manjely Y, Téguia A: Performances zootechniques et caractéristiques morphométriques de la poule locale des zones urbaine et rurale de l'Ouest Cameroun. Livest Res Rural Dev 2007, 19:107 [Retrieved July 1, 2011, from http://www.lrrd.org/lrrd19/8/ keam19107.htm]

54. Fotsa J-C, Rognon $\mathrm{X}$, Tixier-Boichard $\mathrm{M}$, Coquerelle G, Poné Kamdem $\mathrm{D}$, Ngou Ngoupayou JD, Manjeli Y, Bordas A: Caractérisation phénotypique des populations de poules locales (Gallus Gallus) de la zone forestière dense humide à pluviométrie bimodale du Cameroun.Anim Genet Res 2010, 46:49-59.

55. Fotsa J-C, Poné Kamdem D, Rognon X, Tixier-Boichard M, Manjeli Y, Bordas A: Influence de certaines mutations à effets visibles sur les performances pondérales et les mensurations corporelles chez la poule locale de la zone forestière dense humide du Cameroun. Bull Anim Hlth Prod Afr 2009, 57:276-284.

56. Barbok A: Structure et importance des secteurs avicoles commercial et traditionnel au Maroc. In Revue du Secteur Avicole. Edited by FAO.: Animal Production and Health Division; 2008 [available at ftp://ftp.fao.org/docrep/ fao/011/ai377f/ai377f00.pdf].

57. Ngatchou A, Teleu Ngandeu E: Première évaluation du secteur avicole au Cameroun. In Revue du Secteur Avicole. Edited by FAO: Animal Production 
and Health Division; 2008 [available at http://www.fao-ectad-bamako.org/fr/ IMG/pdf/Cameroon_FR_.pdf].

58. Aning KG: The structure and importance of commercial and village based poultry in Ghana. In Revue du Secteur Avicole. Edited by FAO.: Animal Production and Health Division; 2008 [available at http://www.fao-ectadbamako.org/fr/IMG/pdf/Ghana_EN_.pdf].

59. Fanou U: Première évaluation de la structure et de l'importance du secteur avicole commercial et familial en Afrique de l'Ouest. Cas du Bénin. In Revue du Secteur Avicole. Edited by FAO.: Animal Production and Health Division; 2008 [available at http://www.fao-ectad-bamako.org/fr/IMG/ pdf/Benin_FR_pdf].

60. Basheer A, Wilson PW, Talbot RJ, Sharp PJ, Law A, Windsor D, Haley C, Dunn I: Detection of genetic loci for incubation behavior in chickens. Brit Poult Abstr 2010, 6:43-44.

61. Obioha FC, Nwosu CC, Gowen F, Etim DB, Obanu Z, Ihemelandu E, Onuora G: Comparative meat yield and anthropometric indices of the Nigerian native chicken and an exotic strain. World Rev Anim Prod 1983, 19(1): 59-64.

62. Rodriguez $L C$, Herrero M, Baltenweck I: Community-based interventions for the use and conservation of animal genetic resources: the case of indigenous scavenger chicken production in Benin. Trop Anim Health Prod 2011, 43:961-966.

63. Fotsa JC, Poné Kamdem D, Manjeli Y, Ngou Ngoupayou JD: The state of Cameroon rural chickens: Production and development perspectives for poverty alleviation. Ghanaian J Anim Sci 2007, 2-3:175-180.

64. Ekue NF, Poné Kamdem D, Mafeni JM, Nfi AN, Njoya J: Survey of the traditional poultry production system in Bamenda area, Cameroon. In Characteristics parameters of family poultry production in Africa: Results of a FAO/IAEA Co-ordinated Research programme IAEA; 2002:15-25.

65. Cuc NTK, Muchadeyi FC, Baulain U, Eding H, Weigend S, Wollny CBA: An Assessment of Genetic Diversity of Vietnamese H'mong Chickens. Int J Poult Sci 2006, 5:912-920

66. Water resources and irrigation in Africa. [http://www.fao.org/nr/water/ aquastat/watresafrica/index3.stm].

67. Youssao IAK, Senou M, Dahouda M, Kpodékon MT, Djenontin J, Idrissou N-D, Bonou GA, Tougan UP, Ahounou S, Assogba HM, et al: Genetic Improvement of Local Chickens by Crossing with the Label Rouge (T55XSA51): Growth Performances and Heterosis Effects. Int J Poult SCi 2009, 8:536-544.

68. Ki-Zerbo J: Histoire de l'Afrique noire. Paris: Hatier; 1972

69. Baba Kaké I: La dislocation des grands empires. L'Afrique occidentale du XVI' au XVIII siècle. Paris/Dakar: ACCT/Présence Africaine; 1977.

70. Kipre P: Des lagunes ivoiriennes à la Volta. In Histoire générale de l'Afrique IV. L'Afrique du XII au XVI siècle. Edited by Ki-Zerbo J, Niane DT. Paris: Présence Africaine/Edicef/Unesco; 1991:209-218.

71. Tixier-Boichard $M$, Bordas A, Rognon X: Characterisation and monitoring of poultry genetic resources. World Poultry Sci J 2009, 65:272-285.

72. Pariset $L$, Joost $S$, Marsan PA, Valentini A: Landscape genomics and biased FST approaches reveal single nucleotide polymorphisms under selection in goat breeds of North-East Mediterranean. BMC Genet 2009, 10:7.

\section{Submit your next manuscript to BioMed Central and take full advantage of:}

- Convenient online submission

- Thorough peer review

- No space constraints or color figure charges

- Immediate publication on acceptance

- Inclusion in PubMed, CAS, Scopus and Google Scholar

- Research which is freely available for redistribution 